\title{
COVID-19: Analisis Job Insecurity dan Job Engagement Terhadap Job Performance Karyawan Hotel di Semarang
}

\author{
${ }^{1}$ Ray Octafian, ${ }^{2}$ Krisnawati Setyaningrum Nugraheni \\ STIEPARI, Semarang, Indonesia

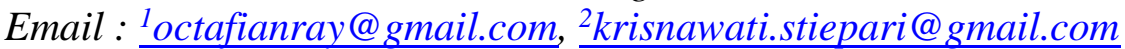

(Diterima: November 2021; Direvisi: Desember 2021; Dipublikasikan: Januari 2022)

\begin{abstract}
ABSTRAK
COVID-19 telah menyebar cukup lama di Indonesia, sejak awal maret 2020 virus corona masuk di Indonesia dan menyebar sangat cepat hingga membuat hotel dan restoran mengalami okupansi sekitar 30\%. Sukamdani (2020) menyatakan jika okupansi turun menjadi 30\%, hotel maupun restoran akan mengambil tindakan efisiensi biaya karyawan dengan melakukan kerja gilir mengakibatkan penerimaan gaji tidak full, menurunkan gaji, gaji tertunda, maupun pemutusan hubungan kerja sementara. Orang asing yang memasuki Indonesia dibatasi maupun turis domestic untuk mencegah penularan COVID-19, hal ini mengancam secara langsung pada keberlangsungan organisasi dan kinerja. Dalam konteks ini, job insecurity yang dialami karyawan hotel mungkin akan signifikan dalam menentukan bagaimana industry dapat pulih dan bertahan. Covid-19 telah memperburuk situasi ini, Job insecurity menyebar diantara karyawan dengan dua alasan, pertama perubahan organisasi menyebabkan job insecurity seperti PHK, perampingan dan merger. Kedua, ancaman yang memicu stress. (Shoss, 2017). Karyawan hotel mempunyai peran penting dalam memuaskan konsumen dengan positif, kepuasan pelanggan dan evaluasi kinerja sangat untuk dijaga. Perubahan lingkungan yang terjadi menimbulkan kecemasan untuk karyawan. Oleh karena itu, peneliti ingin mengetahui efek job insecurity pandemi mempengaruhi job engagement dan job performance.

Penelitian ini dilakukan dengan metode kuantitatif. Populasi dalam penelitian ini adalah karyawan yang bekerja pada hotel berbintang di Semarang. Besar sampel penelitian ditentukan sebesar 100 karyawan dengan tingkat kesalahan $10 \%$. Pengumpulan data mengunakan kuesioner secara daring menggunakan googleform dan wawancara.
\end{abstract}

Kata Kunci: Job Insecurity, Job Engagement, Job Performance 


\section{PENDAHULUAN}

COVID-19 telah menyebar cukup lama di Indonesia, sejak awal maret 2020 virus corona masuk di Indonesia dan menyebar sangat cepat hingga membuat hotel dan restoran mengalami okupansi sekitar 30\%. Sukamdani (2020) menyatakan jika okupansi turun menjadi $30 \%$, hotel maupun restoran akan mengambil tindakan efisiensi biaya karyawan dengan melakukan kerja gilir mengakibatkan penerimaan gaji tidak full, menurunkan gaji, gaji tertunda, maupun pemutusan hubungan kerja sementara.

Orang asing yang memasuki Indonesia dibatasi maupun turis domestic untuk mencegah penularan COVID-19, hal ini mengancam secara langsung pada keberlangsungan organisasi dan kinerja. Dalam konteks ini, job insecurity yang dialami karyawan hotel mungkin akan signifikan dalam menentukan bagaimana industry dapat pulih dan bertahan.

Pada penelitian sebelumnya COVID-19 terjadi lingkungan organisasi telah menghadapi ketidakpastian akibat perubahan teknologi, fluktuasi ekonomi yang membuat karyawan merasa tidak aman. Restrukturisasi dan penggiliran kerja maupun PHK meningkatkan presepsi job insecurity karyawan (Karatepe et al., 2020).

Covid-19 telah memperburuk situasi ini, Job insecurity menyebar diantara karyawan dengan dua alasan, pertama perubahan organisasi menyebabkan job insecurity seperti PHK, perampingan dan merger. Kedua, ancaman yang memicu stress. (Shoss, 2017). Sekarang semuanya telah berubah menjadi aturan new normal. Selama COVID-19, semua organisasi dipaksa untuk melakukan proses pekerjaannya melalui proses digitalisasi dengan bantuan teknologi. Hal itu merupakan tantangan besar bagi organisasi dalam menangani dampak COVID-19 pada karyawan terhadap keselamatan maupun kinerja karyawan (Carnevale et.al., 2020).

Job Engagement didefinisikan sebagai keadaan positif dan memuaskan dengan adanya semangat dan motivasi yang diberikan. Karyawan yang mempunyai fokus, motivasi dan bersemangat mengenai pekerjaan mereka memberikan manfaat kepada perusahaan seperti peningkatan laba dan produktivitas, meningkatkan omset, menghemat biaya, dan meningkatkan citra organisasi.

Secara umum, job engagement mempunyai pengaruh positif pada pekerjaan dan karyawan terhadap job performance karyawan. Job engagement adalah prioritas nomor satu bagi para pemimpin sumber daya manusia. Greenhalgh et al (1984) menyatakan bahwa karyawan dengan $\mathrm{Job}$ Insecurity lebih tinggi menyebabkan job engagement berkurang dalam upaya mencapai tujuan organisasi karena mereka kehabisan waktu dan tenaga untuk pekerjaan mereka. Job insecurity akan berpengaruh negative pada job engagement (Wang, 2015).

Karyawan hotel mempunyai peran penting dalam memuaskan konsumen dengan positif, kepuasan pelanggan dan evaluasi kinerja sangat untuk dijaga. Perubahan lingkungan yang terjadi menimbulkan kecemasan untuk karyawan. Oleh karena itu, peneliti ingin mengetahui efek job insecurity pandemi mempengaruhi 
job engagement dan job performance. Adapun pertanyaan dalam penelitian adalah bagaimana pengaruh job insecurity terhadap job performance karyawan ? Kedua, bagaimana pengaruh job engagement terhadap job performance karyawan ? Ketiga, bagaimana pengaruh job insecurity tehadap job engagement karyawan?

\section{TINJAUAN PUSTAKA}

\section{Job insecurity.}

Job insecurity mencerminkan ancaman terhadap kelangsungan dan stabilitas pekerjaan seperti yang saat ini dialami. Job insecurity telah menjadi fokus meningkatnya perhatian akademis dan populer mengingat perubahan teknologi, ekonomi, dan politik selama beberapa dekade terakhir yang telah meninggalkan banyak rasa tidak aman tentang masa depan pekerjaan mereka (Shoss, 2017).

Job insecurity sebagai ancaman yang dialami secara subyektif, rasa tidak aman kerja diturunkan dari ancaman objektif melalui proses kognitif individu Selama bertahun-tahun, para peneliti telah menunjukkan hasil yang luar biasa minat dalam mengidentifikasi perbedaan individu dan konteks kerja yang dapat melindungi efek negatif dari job insecurity hasil perilaku karyawan (Greenhalgh \& Rosenblatt, 2010).

Job insecurity tampaknya memiliki hubungan negatif yang lebih kuat dengan kinerja kerja di antara karyawan dengan self efficacy yang rendah dibandingkan dengan mereka yang self-efficacy tinggi. Penting untuk dilakukan penelitian lebih lanjut yang mengidentifikasi kondisi kerja di mana kinerja karyawan dipengaruhi secara negatif oleh job insecurity karena temuan ini akan berguna untuk desain dan penyediaan intervensi manajemen. Tidak jarang hal seperti ini diiringi dengan kondisi bahwa seseorang tersebut memiliki kecocokkan dan keterikatan yang tinggi dengan organisasi dimana mereka bekerja. Di satu sisi mereka ingin terus eksis di dalam organisasi tempat mereka bekerja, tetapi di sisi lain mereka merasa bahwa posisinya (pekerjaan dan keberadaannya dalam organisasi) terancam. Menurut (Iqbal \& Halilah, 2017) ada beberapa hal yang menjadi masalah dalam job insecurity diantaranya sebagai berikut:

1. Kondisi pekerjaan adalah segala sesuatu yang ada di sekitar individu yang dimaksud, baik itu berinteraksi langsung maupun tidak langsung dengan pekerja yang bersangkutan. Hal ini meliputi lingkungan kerja beban kerja (kuantitatif dan kualitatif), dan pekerjaan berisiko tinggi

2. Konflik peran. Masalah lain yang timbul adalah ketidakjelasan peran dalam bekerja sehingga tidak tahu apa yang diharapkan manajemen dari diri karyawan tersebut.

3. Pengembangan karir. Ketidakjelasan jenjang karir, penilaian prestasi kerja, seringkali menimbulkan suatu kecemasan terhadap keberlangsungan pekerjaan, rasa bosan, dan dismotivasi 
sehingga karyawan tidak produktif lagi.

Menurut (Iqbal \& Halilah, 2017) job insecurity berdampak pada timbulnya stress kerja yang memiliki efek merugikan pada kesehatan.

\section{Job Engagement}

Job engagement merupakan sebuah motivasi dan pusat pikiran positif yang berhubungan dengan pekerjaan yang ditandai dengan vigor, dedication dan absorption (Karatepe et al., 2020). Penjelasan yang telah diberikan adalah bahwa kinerja pekerjaan efektif ketika karyawan mengalami keadaan pikiran positif dan motivasi aktif, ditandai oleh kasih sayang (dedikasi), energy (semangat) dan inspirasi kognitif (penyerapan) terhadap pekerjaan. Kondisi psikologis khusus inilah yang memotivasi karyawan untuk bekerja keras dan berkinerja baik. Karyawan yang terlibat mendekati pekerjaan mereka secara proaktif (Salanova dan Schaufeli, 2008), lebih dinamis (Bakker dan Leiter, 2010), lebih responsif terhadap informasi baru dan bekerja lebih keras (Bakker dan Leiter, 2010).

Tingkat job engagement yang absolut dapat memengaruhi peningkatan kinerja dari waktu ke waktu, karena diharapkan bahwa keterlibatan individu mengikat kemampuan individu untuk menginvestasikan upaya mereka dalam kegiatan kerja, menghasilkan peningkatan kinerja seiring waktu. Keterlibatan dan upaya yang lebih besar yang dihabiskan untuk pekerjaan, pada gilirannya, kemungkinan akan memprediksi peningkatan kinerja pekerjaan.

\section{Job Performance}

Job performance atau kinerja karyawan melibatkan sikap pekerja yang sesuai dengan tujuan organisasi. Hal tersebut dapat diartikan bahwa kinerja yang dihasilkan dari fungsi suatu pekerjaan tertentu atau hasil dari aktivitas dalam suatu periode tertentu. Keberadaan karyawan dalam suatu organisasi sangat menentukan keberhasilan dan keberlangsungan semua aktivitas organisasi guna mencapai tujuan organisasi. Oleh karena itu, manajemen perlu memberikan dukungan yang kuat dalam memotivasi karyawan untuk bekerja secara professional agar karyawan dapat mencapai kinerja yang sesuai dengan harapan dan organisasinya. Kinerja adalah kontribusi individu baik positif maupun negatif yang diberikan individu dalam organisasi (Ratnasari,2019).

\section{METODE PENELITIAN}

\section{Waktu dan Tempat Penelitian}

Penelitian dilakukan pada bulan Maret 2021 - Agustus 2021. Pemilihan lokasi penelitian di hotel Patrajasa Semarang

\section{Populasi dan Sampel}

Populasi adalah keseluruhan subjek penelitian, Populasi dalam penelitian ini adalah karyawan yang bekerja pada hotel bintang di Semarang. Besar sampel penelitian ditentukan sebesar 100 karyawan dengan tingkat kesalahan $10 \%$.

Pengumpulan data dan survey dilakukan secara sukarela setelah mendapat ijin dari manager 
SDM hotel tersebut. Data yang dikumpulkan dari responden akan dirahasiakan. Kami memulai survey setelah kami menjelaskan tujuan penelitian kepada responden. Metode sampling yang digunakan adalah metode accidental sampling, yaitu pengambilan sampel yang dilakukan dengan menunjuk siapa saja atau secara kebetulan.

Skala kuesioner menggunakan skala likert 5 poin untuk menanggapi pertanyaan "seberapa anda setuju atau tidak setuju dengan pernyataan ini?”. (1: sangat tidak setuju hingga 5 sangat setuju)

\section{Sumber Data}

Sumber data yang digunakan dalam penelitian adalah

1. Data primer,

Data Primer, yaitu data yang diperoleh langsung dari sumbernya, diamati dan dicatat untuk pertama kalinya, data primer diperoleh menggunakan kuesioner yang dilakukan secara online menggunakan googleform.

2. Data sekunder

Data sekunder adalah data yang diperoleh secara tidak langsung, baik berupa keterangan maupun literatur yang ada hubungannya dalam penelitian yang sifatnya melengkapi atau mendukung data primer. Dalam penelitian ini data sekunder bersumber dari studi pustaka melalui berbagai jurnal, buku, maupun artikel penelitian

\section{Teknik Pengumpulan Data}

Penelitian ini menggunakan teknik pengumpulan data yaitu kuesioner dan wawancara. Metode ini

bertujuan memperoleh data primer dengan kuesioer berisi pertanyaan tertutup dengan alternatif jawaban yang sudah disiapkan. Pengisian kuesioner menggunakan bantuan www.googleform.com.

Wawancara merupakan proses pengumpulan data dengan cara melakukan interview

\section{Variabel} adalah :

Variabel dalam penelitian ini

1) Job Insecurity (De Witte, 2000)

2) Job Engagement (Schaufeli, 2006)

3) Job Performance (Babin and Boles, 1998)

\section{Analisis Data}

Penelitian ini dilakukan dengan metode kuantitatif. Setelah data terkumpul, data di analis menggunakan SPSS dan AMOS. teknik analisis SEM menurut Hair, C.Black, J.Babin, \& Anderson (2010).

Analisis penelitian dilakukan dalam empat tahapan. Pertama, validitas konstruk masing-masing model pengukuran dengan analisis Confirmatory Factor Analysis (CFA). Kedua, melakukan statistik deskriptif, korelasi, dan reliabilitas. Ketiga, analisis regresi linier berganda. Keempat, analisis model structural.

Model terbaik dipilih, berdasarkan pertimbangan teoritis dan perbandingan indeks statistic menggunakan AMOS 23. Statistik deskriptif, korelasi, keandalan, dan analisis regresi berganda hierarki dilakukan, menggunakan IBM SPSS Statistics 25 (Brian Joo \& 
Lim, 2013; Hair, J. F., Black, W. C., Babin, B. J. and Anderson, 2010).

\section{HASIL PENELITIAN Profil Patra Hotel \& Convention}

Patra hotel \& convention terletak di Candibaru, Semarang. Merupakan hotel yang mempunya MICE terbaik di Semarang dengan 146 kamar dan villa serta swimming pools private. Two large confeence rooms Grand Rama Shinta dan Poncowati yang memuat hingga 3000 tamu dengan parkir mobil yang luas, sehingga sangat cocok untuk acara konferensi, rapat maupun wedding ceremoni.

\section{Gambaran Responden}

Sampel yang terkumpul sebanyak 95 responden dari 100 kuesioner yang kami sebarkan. Responden yang berpartisipasi merupakan karyawan patra hotel Semarang. Dalam penyebaran kuesioner dilakukan melalui googleform

https://forms.gle/BD68cT6y2ckG4hy c6 yang kami sebarkan melalui HR Patra Hotel. Dekripsi responden dibedakan menjadi tiga yaitu responden berdasarkan jenis kelamin, status pekerjaan dan lama bekerja. Berdasarkan hasil output SPSS pada Tabel 1 menunjukkan responden Pria sebesar $60,4 \%$ atau 34 responden lebih besar dibandingkan responden berjenis kelamin wanita sebesar $35,8 \%$ atau 34 responden. Responden berdasarkan status pekerjaan menunjukan bahwa karyawan Patra
Hotel lebih dominan berstatus sebagai karyawan Tetap sebesar 60,4 \% dibandingkan karyawan kontrak sebesar 34\%. Serta responden dengan lama bekerja lebih dari 5 tahun menempati posisi paling dominan sebesar 68,3\%, responden lama bekerja 1 hingga 5 tahun sebesar $23 \%$ dan lama bekerja kurang dari 1 tahun sebesar 3\%. Hal ini menunjukan bahwa rata-rata karyawan yang bekerja di Patra Hotel merupakan karyawan yang sudah berpengalaman.

Tabel 1. Karakteristik Responden

\begin{tabular}{|c|c|c|c|}
\hline No & Karakteristik & Frekuensi & $\begin{array}{c}\text { Persentase } \\
(\%)\end{array}$ \\
\hline 1 & \multicolumn{3}{|c|}{ Jenis Kelamin } \\
\hline & Wanita & 34 & 35,8 \\
\hline & Pria & 61 & 60,4 \\
\hline 2 & \multicolumn{3}{|c|}{ Status Pekerjaan } \\
\hline & Tetap & 61 & 60,4 \\
\hline & Kontrak & 34 & 33,7 \\
\hline 3 & \multicolumn{3}{|c|}{ Lama Bekerja } \\
\hline & $\begin{array}{l}\text { Kurang dari } 1 \\
\text { Tahun }\end{array}$ & 3 & 3 \\
\hline & $\begin{array}{l}1 \text { hingga } 5 \\
\text { Tahun }\end{array}$ & 23 & 22,8 \\
\hline & $\begin{array}{l}\text { Lebih dari } 5 \\
\text { Tahun }\end{array}$ & 69 & 68,3 \\
\hline
\end{tabular}

Sumber : Hasil Output (2021)

\section{Model pengukuran}

Penelitian ini mengumpulkan data menggunakan kuesioner. Analisis mengkonfirmasi validitas konvergen dan diskriminan sebagai serta keandalan properti, seperti yang ditunjukkan. Koefisien standar untuk semua item pengukuran adalah 0,8 atau lebih tinggi. Alpha Cronbach, CCR, dan AVE juga 0,8 atau lebih tinggi (Amoako-Asiedu \& ObuobisaDarko, 2017; Hair et al., 2010). Kecocokan model memuaskan $\left(\mathrm{X}^{2}=\right.$ 
$210 ; \mathrm{df}=167 ; \mathrm{X}^{2} / \mathrm{df}=1180,117 ; \mathrm{GFI}$

$=0,914 ; \mathrm{NFI}=0,910 ; \mathrm{CFI}=0,944$;

dan RMSEA $=0,052)$, dilihat dari

derajat kebebasannya.

Tabel 2. Reliability dan confirmatory factor analysis

\begin{tabular}{|c|c|c|c|}
\hline Konstruk & $\begin{array}{c}\text { Standardi } \\
\text { zed } \\
\text { Estimate }\end{array}$ & SMC & $\begin{array}{l}\text { Cronbach } \\
\text { 's alpha }\end{array}$ \\
\hline$J o b$ & & & 0,883 \\
\hline \multicolumn{4}{|l|}{ Insecurity } \\
\hline $\mathrm{JI} 2$ & 0,821 & 0,820 & \\
\hline JI3 & 0,801 & 0,841 & \\
\hline JI5 & 0,930 & 0,865 & \\
\hline JI6 & 0,864 & 0,840 & \\
\hline JI7 & 0,884 & 0,881 & \\
\hline JI9 & 0,852 & 0,825 & \\
\hline$J o b$ & & & 0,972 \\
\hline \multicolumn{4}{|l|}{ Engagement } \\
\hline JE1 & 0,945 & 0,893 & \\
\hline JE2 & 0,914 & 0,835 & \\
\hline JE3 & 0,936 & 0,876 & \\
\hline JE4 & 0,973 & 0,946 & \\
\hline JE5 & 0,843 & 0,811 & \\
\hline JE6 & 0,953 & 0,908 & \\
\hline JE7 & 0,868 & 0,853 & \\
\hline JE8 & 0,813 & 0,861 & \\
\hline$J o b$ & & & 0,828 \\
\hline \multicolumn{4}{|l|}{ Performanc } \\
\hline$e$ & & & \\
\hline JP1 & 0,890 & 0,825 & \\
\hline JP2 & 0,964 & 0,930 & \\
\hline JP3 & 0,958 & 0,918 & \\
\hline JP4 & 0,960 & 0,921 & \\
\hline JP6 & 0,803 & 0,894 & \\
\hline JP8 & 0,880 & 0,609 & \\
\hline
\end{tabular}

Sumber : Hasil Output (2021)

Note:

$\chi^{2}=210(\mathrm{df}=167) \mathrm{p}<.000 ; \chi^{2} / \mathrm{df}=$ 1.180,117; Goodness of Fit Index (GFI) $=.914 ;$ Normed Fit Index $(\mathrm{NFI})=.910$; Comparative Fit Index $(\mathrm{CFI})=.944$; Root-Mean Square Error of Approximation $(\mathrm{RMSEA})=.052 ; * * * \mathrm{p}$ $<$.001. SMC $=$ Squared multiple correlations

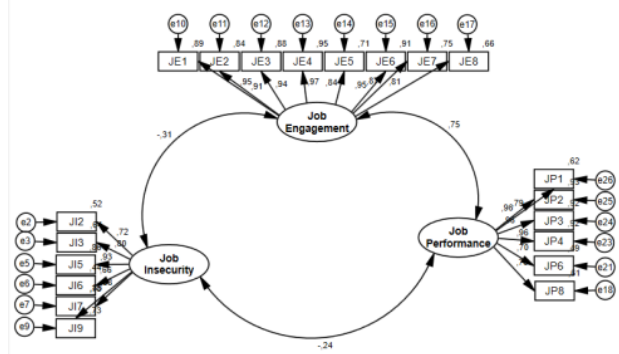

Gambar 1. Pengukuran Model Tabel 4. Structural Parameter

\section{Estimates}

\begin{tabular}{lccc}
\hline Hypothesized Path & Estimate & C.R & Result \\
\hline $\begin{array}{l}\text { Job insecurity } \rightarrow \\
\text { Job Engagement }\end{array}$ & $-0,314$ & $-2,612$ & Support \\
$\begin{array}{l}\text { Job Engagement } \rightarrow \\
\text { Job Performance }\end{array}$ & 0,754 & 4,818 & Support \\
$\begin{array}{l}\text { Job Insecurity } \rightarrow \\
\text { Job Performance }\end{array}$ & $-0,238$ & $-2,068$ & Support \\
\hline Sumber & & & \\
\hline
\end{tabular}

Sumber : Hasil Output (2021)

\section{Structural Equation Modeling (SEM)}

Hubungan yang terkait dengan hipotesis dianalisis menggunakan SEM (Structural Equation Modeling). Tabel 4 menunjukkan koefisien jalur standar dan nilai $t$ untuk semua hubungan dalam model struktural. SEM dilakukan untuk menguji Hipotesis 1, 2, dan 3, dan model struktural fit baik $\left(X^{2}=210\right.$; $\mathrm{X}^{2} / \mathrm{df}=1180,117 ; \mathrm{GFI}=0,914 ; \mathrm{NFI}$ $=0,910 ; \mathrm{CFI}=0,944)$. Hipotesis 1 , yang menghipotesiskan hubungan negatif antara ketidakamanan kerja dan keterlibatan kerja, didukung $(\beta=$ $-0.314 ;$ C. $R=-2,612$ ). Hal ini menunjukkan bahwa, karena persepsi ketidakamanan kerja lebih tinggi selama pandemi COVID-19, orang cenderung tidak terlibat dan terlibat dalam pekerjaan mereka. Selanjutnya, job engagement mempengaruhi job performance $(\beta=0,754 ;$ C.R $=$ 4,818), yang mendukung Hipotesis 2. Hal ini menunjukkan bahwa job 
engagement meningkat seiring dengan peningkatan job performance. Namun, Hipotesis 3, yang memprediksi hubungan negatif antara job insecurity dan job performance $(\beta$ $=-0,238 ;$ C.R $=-2,068)$. Dalam penelitian ini, persepsi job insecurity tidak berpengaruh signifikan dan langsung terhadap Job Performance.

\section{PENUTUP}

\section{Simpulan}

Dari hasil penelitian dan pembahasan yang telah diuraikan, dapat disimpulkan bahwa job insecurity adalah akibat dari keadaan mental karyawan karena merasa ambigu, bingung dan tidak aman tentang rasa memiliki terhadap organisasi dengan perubahan kondisi di lingkungan kerja yang mengancam Penelitian oleh (Iqbal dan Halilah, 2017; Wang et al., 2015) menemukan pekerjaan itu ketidakamanan memiliki dampak negatif dan signifikan terhadap kinerja, yang menyebabkan penurunan karyawan pertunjukan. Hasil Asfaw and Chang (2019) menegaskan bahwa job insecurity memiliki dampak positif dan dampak signifikan terhadap kinerja pegawai; Keterikatan karyawan adalah salah satu variabel yang mempengaruhi kinerja karyawan. tingkatkan kinerja Anda lebih baik.Gröbelna, 2019; Hewagama dkk., 2020; Sahani, 2021; Wang et al., 2015, menunjukkan dalam studi mereka bahwa keterlibatan karyawan memiliki berpengaruh positif dan signifikan terhadap kinerja pegawai, sehingga dapat dikatakan peningkatan pegawai keterlibatan dapat meningkatkan kinerja mereka.

\section{DAFTAR PUSTAKA}

Aguiar-Quintana, T., Nguyen, H., Araujo-Cabrera, Y., \&amp; Sanabria-Díaz, J. M. (2021). Do job insecurity, anxiety and depression caused by the COVID-19 pandemic influence hotel employees' self-ratedtask performance? The moderating role of employee resilience. International Journal of Hospitality Management, 94(June 2020). https://doi.org/10.1016/j.ijhm.2 $\underline{021.102868}$

Aktar, A., \&amp; Pangil, F. (2017). The Relationship between Employee Engagement, HRM practices and Perceived Organizational Support: Evidence from Banking Employees. International Journal of Human Resource Studies, $\quad 7(3), \quad 1$. https://doi.org/10.5296/ijhrs.v7 i3.11353

Anwar Sanusi. (2016). Metode Penelitian Bisnis (Vol. 6). Salemba Empat.

Asfaw, A. G., \&amp; Chang, C.-C. (2019). The association between job insecurity and engagement of employees at work.

Https://Doi.Org/10.1080/15555 240.2019.1600409, 34(2), 96110.

https://doi.org/10.1080/155552 40.2019.1600409

Azka, G., Tahir, M. Q., M, A. K., \&amp; Syed, T. H. (2011). Transformational leadership, employee engagement and performance: Mediating effect of psychological ownership. African Journal of Business 
Management, 5(17), 73917403.

https://doi.org/10.5897/ajbm11. 126

Bakker, A. B., Albrecht, S. L., \&amp; Leiter, M. P. (2011). Key questions regarding work engagement.

European Journal of Work and Organizational Psychology. https://doi.org/10.1080/135943 2X.2010.485352

Greenhalgh, L., \&amp; Rosenblatt, Z. (2010). Evolution of research on job insecurity. International Studies of Management and Organization.

https://doi.org/10.2753/IMO00 20-8825400101

Grobelna, A. (2019). Effects of individual and job characteristics on hotel contact employees' work engagement and their performance outcomes: A case study from Poland. International Journal of Contemporary Hospitality Management, 31(1), 349-369. https://doi.org/10.1108/IJCHM -08-2017-0501

Hair, joseph F., C.Black, W., J.Babin, B., \&amp; Anderson, R. E. (2010). Multivariate Data Analysis Seventh Edition. https://doi.org/10.1016/j.ijphar m.2011.02.019

Hewagama, G., Boxall, P., Cheung, G., \&amp; Hutchison, A. (2019). Service recovery through empowerment? HRM employee performance and job satisfaction in hotels. International

Journal of Hospitality Management, 81(March), 73-82. https://doi.org/10.1016/j.ijhm.2 019.03 .006

Iqbal, M., \&amp; Halilah, I. (2017). Pengaruh Job Insecurity Terhadap Turnover Intention. Jurnal Riset Bisnis Dan Investasi, 3(1), 98-108.

Ismail, H. N., Iqbal, A., \&amp; Nasr, L. (2019). Employee engagement and job performance in Lebanon: the mediating role of creativity. International Journal of Productivity and Performance Management, 68(3), 506-523. https://doi.org/10.1108/IJPPM02-2018-0052

Karatepe, O. M., Rezapouraghdam, H., \&amp; Hassannia, R. (2020). International Journal of Hospitality

Management Job insecurity, work engagement and their e ff ects on hotel employees ' non- green and nonattendance behaviors. International Journal of Hospitality Management, 87(February), 102472. https://doi.org/10.1016/j.ijhm.2 020.102472

Kim, M., Lee, J., \&amp; Kim, J. (2019). The Role of Grit in Enhancing Job Performance of Frontline Employees: The Moderating Role of Organizational Tenure. 15, 6184.

https://doi.org/10.1108/s1745354220190000015004

Köse, A., \&amp; Uzun, M. (2018). The Relationship between Work Engagement and Perceived Organizational Justice. Educational Administration: Theory and Practice, 
24(3).https://doi.org/10.14527/ kuey.2018.012

Macey, W. H. (2009). Employee engagement : tools for analysis, practice, and competitive advantage. 203.

P.G.Lewiuci \&amp; Ronny H. Mustamu. (2016). Pengaruh Employee Engagement terhadap Kinerja Karyawan pada Perusahaan Keluarga Produsen Senapan Angin. Agora Journal, 4(2), 101-107.

Rabiul, M. K., \&amp; Yean, T. F. (2021). Leadership styles, motivating language, and work engagement: An empirical investigation of the hotel industry. International Journal of Hospitality Management, 92(September 2020), 102712. https://doi.org/10.1016/j.ijhm.2 020.102712

Sahni, J. (2021). Employee Engagement Among Millennial Workforce: Empirical Study on Selected Antecedents and Consequences. SAGE Open, 11(1).https://doi.org/10.1177/2 1582440211002208
Schaufeli, W. B., Bakker, A. B., \&amp; Salanova, M. (2006). The measurement of work engagement with a short questionnaire: A cross-national study. Educational and Psychological Measurement, 66(4), 701-716. https://doi.org/10.1177/001316 4405282471

Shoss, M. K. (2017). Job Insecurity: An Integrative Review and Agenda for Future Research. Journal of Management, 43(6), 1911-1939.

https://doi.org/10.1177/014920 6317691574

Wang, H. J., Lu, C. Q., \&amp; Siu, O. L. (2015). Job insecurity and job performance: The moderating role of organizational justice and the mediating role of work engagement. Journal of Applied Psychology, 100(4), 12491258. https://doi.org/10.1037/a00383 30 